\title{
Optimum Farm Plan for Higher Net Income in Southern and Eastern Dry Zone of Karnataka
}

\author{
Bhavya, A.P. ${ }^{1 *}$, Raghupathi, R. ${ }^{2}$ and Umesh, K.B. ${ }^{2}$ \\ ${ }^{1}$ Project Associate, ICAR-NIVEDI, Bengaluru, India \\ ${ }^{2}$ Department of Agricultural Economics, UAS, GKVK, Bengaluru, India \\ *Corresponding author: bhavya816@gmail.com (ORCID ID: 0000-0002-4554-9940)
}

Received: 03-06-2021

Revised: $13-08-2021$

Accepted: 03-09-2021

\begin{abstract}
The present study was focused on deriving an optimum farm plan which would enhance the farm income in different farming systems in Southern and Eastern dry zones of Karnataka. Data collected from 240 respondents selected using random sampling technique from two districts viz. Mandya and Kolar. The dominant farming systems identified in the study areas were crop + dairy, crop + sheep rearing, Crop + dairy + sericulture, and crop + dairy + horticulture. Linear programming technique was used to work out the maximum attainable return. In Mandya district, crop + sheep farming system were providing an annual income of ₹ 92468 per farm with the total expenditure of ₹ 175400, whereas, an optimal plan can fetch a return of ₹ 278810 per farm with the similar expenditure. In Kolar district, crop + dairy was giving annual income of ₹ 168216 per farm with the total expenditure of ₹ 150000 and through an optimum plan, a farmer could earn ₹ 327996 per farm. Mandya district In farming system with the component of crop + dairy + sericulture, farmers were realizing an annual income of ₹ 296433 per farm with the total expenditure of ₹ 274947, where optimization can provide the farmer an income of ₹ 640487 per farm with similar expenditure and this system is turned out to be most remunerative among all the farming systems.

\section{Highlights}

( Adoption of location specific optimum farm plan would help farmers to enhance the income, in this research crop + dairy + Sericulture farming system realized maximum net annual income in both districts followed by crop + dairy + horticulture system.
\end{abstract}

Keywords: Farming system, Linear programming, Optimum farm plan

Indian agricultural policy in the past has exclusively focused on increasing the production and productivity of crops and livestock. Starting from Green revolution, the production of crops and animal products has registered significant progress. But, the farmer's income and welfare has not necessarily progressed in the same direction. Many factors like fragmentation and divisions of land, raising input cost, unfavorable terms of trade in favor of agriculture and increased risks due to climate change causing pessimistic effect on the interest in farming, farm investments and is also forcing more and more producers, particularly younger age group to leave out farming. This can cause detrimental effect on agriculture future in the country (Surjith, 2017).

Indian agriculture flourished over the last five and half decades, that due to initiation of Green Revolution technologies, has assisted in an era of self-reliance in foodgrain production 295.67 million tonnes (https://eands.dacnet.nic.in). Consistent efforts made by researchers, farmers and policy makers transformed India from shortage to surplus

How to cite this article: Bhavya, A.P., Raghupathi, R. and Umesh, K.B. (2021). Optimum Farm Plan for Higher Net Income in Southern and Eastern Dry Zone of Karnataka. Economic Affairs, 66(3): 459-465.

Source of Support: None; Conflict of Interest: None (c) 9 
food production status within a short period of a decade or so. Apparently, this proved a matter of national pride and great satisfaction to the scientists and farmers of the country (Falcon et al. 2005). In the past research in our country focused on raising agricultural output and improving food security. The net result has been a 45 per cent increase in per person food production along with the food grain production growth from 51 million tonnes during 1947-48 to 297.5 million tonnes during 2019-20. (www.fao.stat.org).

Many a times we attribute this achievement to research and development during green revolution, irrigation infrastructure, fertilizers and pesticides, increase in cultivable area, etc. Though the contribution of all these factors cannot be ignored, it is important to appreciate the role of the farmer who executes and makes available the food from plough to plate. As mentioned before, past policy thrust has been excessively towards increasing production and productivity and not on enhancing profitability and income. Augmenting productivity of crops is only a necessary but not a sufficient condition to raise the farm income (Narayanamoorthy, 2017). The net result has been that farmer's income remained low. Considering the need of enhancing farmer's income, the Government of India explicitly expressed its intention to double the farmers in income by 2022 .

The concept of doubling farmer's income has become a buzz word after the Prime Minister of India stated that it is his dream to see farmers double their income by 2022, when the country complete 75 years of its independence. To achieve this, Government of India has introduced several programs like e- NAM, Pradhan Mantri Gram Sinchai Yojana (PMGSY), per drop more crop, Soil health card, Pradan Mantri Fasal Bhima Yojana, PM-KUSUM to mention a few. But the expected results are not achieved. All India Rural Financial Inclusion Survey (NAFIS) conducted by NABARD shows that average agriculture household income was ₹ 8,931 per month in 2016-17. But shocking is that, the income of the farm households has increased just by ₹ 2505/month from 2012-13 to 2016-17 (Jitendra, 2018).

In this background, it is important to understand the ways and means by which farm income can be enhanced. While computing the income from farming, farming system approach can provide more comprehensive and detailed picture. Farming system aim for increased productivity, profitability, food and nutritional security, sustainability, recycling of unutilized resources, generation of income round the year and through resource reallocation there is a possibility of increasing the farm income (Zainab, 2010). The preset study uses linear programming technique to derive an optimum farm plan, in which maximum possible farm income can be indicated within the boundaries imposed by resource constraints in the Southern and Eastern dry zone of Karnataka.

\section{METHODOLOGY}

\section{Nature and source of the data}

Both primary and secondary data were collected and used for the analysis. Data collection for the study was through well structured questionnaires administered on 240 respondents (120 each from Mandya and Kolar district) selected through random sampling technique. The primary data required for the study viz., socio- economic characteristics, land holdings, inventory of implements and machinery, cost and returns of principal crops, consumption-expenditure and constraints faced by the farmers in farming systems were collected and Secondary data includes socio and demographic characteristics, cropping pattern, land utilization and rainfall pattern of the study area were collected from the Directorate of economics and statistics, Kolar, Mandya and State Agriculture Department Bengaluru.

\section{Analytical tools and techniques}

Linear programming technique formed the basis for obtaining the optimal solution for the different farming systems practiced by the sample farmers. Linear programming is a type of mathematical programming that is concerned with or useful for allocation of scarce or limited resources to several competing activities on the basis of given criterion of optimality (Akpan, 2016). Optimization techniques are widely used in many developing countries to solve the problems of industry and industrialization (Datta and Bandyopadhyay, 1994; Bhat et al. 2015). These techniques have proven its effect in manufacturing sector, marketing sector. Also, it has great potential to use effectively in health care 
management (Bhat et al. 2015). The optimization techniques are very useful for model-based land use allocation and management. This approach allows the decision-makers to explore a large number of land use combinations (Memmah et al. 2015) also helps to optimize the amount of land for each type of crop, especially for the rabi season, in order to maximize the farmgate price and minimize the cost of production to help policy makers for devising better policy to ensure food security of the country (Homayora et al. 2020) and achieving efficiency in production planning, particularly in achieving increased agricultural productivity (Igwe et al. 2011).

The optimum linear programming technique was employed to work out the maximum attainable returns from different farming systems through the optimal allocation of various crop and livestock using available resources. Linear Programming method is one of the most powerful and effective tool for analysis when the available resources are limited (Ezema and Amaken, 2012; Majeke et al. 2013).

\section{Mathematical formulation of the model}

In linear programming analysis, a linear function of number of variables (activities) is to be maximized subject to a number of constraints in the form of linear equalities and inequalities. In mathematical form for one year, the linear programming model can be formulated in the following way (Mark, 1998).

Maximize $\mathrm{Z}=\sum_{i=1}^{n} N_{i} X_{i} \quad$ for $i=1,2,3,4 \ldots N$ is the number of crops

Subject to the constraints:

$$
\begin{array}{ll}
\text { 1. } & \sum_{i=1}^{n} a_{i j} X_{j} \leq b_{i}(i=1 \ldots \ldots . . k) \\
\text { 2. } & \sum_{i=1}^{n} a_{i j} X_{j} \leq b_{i}(j=1 \ldots \ldots . m) \\
\text { 3. } & \sum_{i=1}^{n} a_{i j} X_{j} \leq b_{i}(i=1 \ldots \ldots . n)
\end{array}
$$

Where,

$Z=$ net return (₹) from all crops included in the model

$N_{i}=$ Net return from the $i^{\text {th }}$ crop (₹/ha),

$X_{i}=$ Crop area under $i^{\text {th }}$ crop (ha) (decision variable)

$a_{i j}=$ quantity of $i^{\text {th }}$ input required per unit of the $j^{\text {th }}$ activity

$b_{\mathrm{i}}=$ Quantity available of the $i^{\text {th }}$ resources

\section{Selection of processes or activities}

To know the activities practiced by the farmers is very important to bring the optimum farm plan for profit maximization problems through linear programming technique. An understanding of the availability of resources and the competition for these scarce resources by the enterprise is equally important. The sample farmers were found to follow certain farming systems consisting of crops, vegetables, plantations, floriculture, dairy, sericulture and sheep/goat rearing with different combinations. The components of each farming system, forms the activities in the model.

\section{Constraints and requirements}

The important constraints used in the study were, land (irrigated and rainfed), working capital, availability of family labour, fodder requirement, FYM, limit of barrowing, family requirement of ragi and milk.

1. Land: The average land of the sample farmers under all the crops in the particular farming system was taken as available land, which was further dividend into irrigated and rain fed land.

2. Family labour: Average number of the people engaged in agricultural activity in each family is considered as labour availability.

3. Working capital: Average net returns obtained from all the crops grown by the farmers is deducted by average borrowed amount. The remaining amount is considered as a maximum working capital.

4. Fodder requirement: by-product of ragi, paddy, cowpea, maize, etc. considered as availability of fodder for livestock.

5. Non negativity constraints: The variables in the linear programs must be greater than or equal to zero and the returns or inputs should not be negative. i.e.

$X_{i}>0$

\section{RESULTS AND DISCUSSION}

Objective of the integrated farming systems is not only efficient utilization of farm resources but also contribute to stability of income through interaction effect. Income, input utilization and cropping 
pattern in existing resources and normative plans for crop + sheep farming system in the study area is given in Table 1 . In the existing resources farmers were realizing an annual income of ₹ 92468/ farm / annum with the working capital ₹ 76288, family labour of 523 man days. In an optimum plan by spending ₹ 58871 per farm per annum farmers could earn ₹ 110313 per farm per annum. It is almost 19 per cent more than the existing plan by spending 22 per cent less than available capital. The optimum plan suggests farmers to allocate more area towards ragi ( $0.8 \mathrm{ha}$ ) followed by sugarcane ( $0.5 \mathrm{ha}$ ) with one sheep flock (20 sheep).

Table 1: Income, input utilization and cropping pattern in existing and optimum plans for crop + sheep farming system

\begin{tabular}{|c|c|c|c|c|c|}
\hline $\begin{array}{l}\text { Sl. } \\
\text { No. }\end{array}$ & Particular & $\begin{array}{l}\text { Existing } \\
\text { Mandya }\end{array}$ & $\begin{array}{l}\text { plan } \\
\text { Kolar }\end{array}$ & $\begin{array}{l}\text { Optimun } \\
\text { Mandya }\end{array}$ & $\begin{array}{l}\text { m plan } \\
\text { Kolar }\end{array}$ \\
\hline 1 & Area (ha) Rainfed & 0.50 & 0.82 & 0.50 & 0.82 \\
\hline & Irrigated & 0.80 & 0.12 & 0.80 & 0.12 \\
\hline 2 & Income (₹) & 92468 & 87805 & 110313 & 101787 \\
\hline \multicolumn{6}{|c|}{ Input utilization } \\
\hline 3 & $\begin{array}{l}\text { Working or } \\
\text { available capital (₹) }\end{array}$ & 76288 & 83078 & 58871 & 40578 \\
\hline 4 & $\begin{array}{l}\text { Family labour (man } \\
\text { days) }\end{array}$ & 523 & 520 & 523 & 520 \\
\hline 5 & Fodder $(q)$ & 17 & 14 & 3.84 & 9.15 \\
\hline 6 & FYM (t) & 2 & 2.20 & 4.60 & 3.50 \\
\hline 7 & Borrowed capital (₹) & 40000 & 30000 & 0 & 0.00 \\
\hline 8 & $\begin{array}{l}\text { Ragi consumption } \\
\text { per household }(\mathrm{kg})\end{array}$ & 250 & 254 & 1118 & 1684 \\
\hline \multicolumn{6}{|c|}{ Cropping pattern } \\
\hline 9 & Ragi & 0.12 & 0.64 & 0.80 & 1.28 \\
\hline 10 & Sugarcane & 0.28 & - & 0.50 & - \\
\hline 11 & Paddy & 0.32 & - & 0.00 & - \\
\hline 12 & Cowpea & 0.04 & 0.08 & - & - \\
\hline 13 & Jowar & - & 0.16 & - & - \\
\hline 14 & Maize & - & - & - & 0.12 \\
\hline 15 & Redgram & - & 0.28 & - & - \\
\hline 16 & Sheep & 25.00 & 28.00 & $1.00^{*}$ & $1.00^{*}$ \\
\hline
\end{tabular}

Note: "indicate the one flock (20 sheep).

In case of Kolar district, farmers who adopted crop + sheep farming were realizing an annual income of ₹ 87805 per farm per annum with the total available capital of ₹ 83078 . In an optimum plan by spending ₹ 40578 per farm per annum, farmers can earn ₹ 101787 per farm per annum, which is almost 13 per cent more than the existing plan by spending
53 per cent less. An optimum plan suggested farmers to allocate more area towards ragi (1.28 ha) followed by maize ( $0.12 \mathrm{ha}$ ) with one sheep flock. In the existing situation, farmers average borrowing amount were ₹ 40000 and ₹ 30000 in Mandya and Kolar district, respectively, but optimum plan didn't suggested borrowing of money with the interest rate of 12 per cent per annum.

Table 2: Income, input utilization and cropping pattern in existing and optimum plans for crop + dairy farming system

\begin{tabular}{|c|c|c|c|c|c|}
\hline \multirow{2}{*}{$\begin{array}{l}\text { Sl. } \\
\text { No. }\end{array}$} & \multirow{2}{*}{ Particular } & \multicolumn{2}{|c|}{$\begin{array}{l}\text { Existing } \\
\text { resources }\end{array}$} & \multicolumn{2}{|c|}{ Optimum plan } \\
\hline & & Mandya & Kolar & Mandya & Kolar \\
\hline \multirow[t]{2}{*}{1} & Area (ha) Rainfed & 0.40 & 0.92 & 0.40 & 0.92 \\
\hline & Irrigated & 0.90 & 0.22 & 0.19 & 0.22 \\
\hline 2 & Income (₹) & 111303 & 168216 & 276100 & 115448 \\
\hline \multicolumn{6}{|c|}{ Input utilization } \\
\hline & $\begin{array}{l}\text { Working or available } \\
\text { capital (₹) }\end{array}$ & 90016 & 132611 & 123412 & 71391 \\
\hline 4 & $\begin{array}{l}\text { Family labour (man } \\
\text { days) }\end{array}$ & 432 & 612 & 294 & 120 \\
\hline 5 & Fodder $(q)$ & 11.80 & 26 & 388 & 125 \\
\hline 6 & FYM (t) & 15.90 & 3.40 & 9.45 & 2.00 \\
\hline 7 & Borrowed capital (₹) & 38183 & 59031 & 38183 & 0 \\
\hline 8 & $\begin{array}{l}\text { Ragi consumption } \\
\text { per household (kg) }\end{array}$ & 230 & 230 & 230 & 1207 \\
\hline 9 & $\begin{array}{l}\text { Milk consumption } \\
\text { per household (lt.) }\end{array}$ & 360 & 385 & 11520 & 3856 \\
\hline \multicolumn{6}{|c|}{ Cropping pattern } \\
\hline 10 & Ragi & 0.28 & 0.36 & 0.14 & 0.92 \\
\hline 11 & Cowpea & 0.12 & 0.08 & 0.00 & 0.00 \\
\hline 12 & Sesamum & 0.20 & - & 0.00 & - \\
\hline 13 & Cotton & 0.20 & - & 0.00 & - \\
\hline 14 & Horsegram & 0.04 & 0.20 & 0.00 & 0.00 \\
\hline 15 & Maize & 0.40 & - & 0.19 & - \\
\hline 16 & Rainfed paddy & - & 0.42 & - & 0.00 \\
\hline 17 & Redgram & - & 0.32 & - & 0.00 \\
\hline 18 & Mango & - & 0.20 & - & 0.22 \\
\hline 19 & Coconut & 0.08 & - & 0.25 & - \\
\hline 20 & Dairy animal & 2.00 & 2.00 & 3.00 & 1.00 \\
\hline
\end{tabular}

Income, input utilization and cropping pattern in existing and normative plans for crop + dairy farming system in the study area is given in Table 2 . In the existing cropping plan, farmers were realizing an annual income of ₹ 111303 per farm per annum with the available capital of $₹ 90016$. In an optimum plan by spending ₹ 123412 per farm per annum, 
farmers could earn ₹ 276100 per farm per annum, which is almost 148 per cent more than the existing plan by spending 37 per cent less than the existing spending pattern. In existing situation, more area allocated for maize ( 0.4 acre) followed by ragi ( 0.28 ha). An optimum plan suggested farmers to allocate more area towards coconut $(0.25 \mathrm{ha})$ followed by ragi ( 0.14 ha) with 3 dairy animals. The result of the study was on par with the research conducted by Tamta et al. (2016), who revealed that farm income under an existing farm plan was ₹ 34103, which could be increased up to ₹ 37828 under optimum plan. Thus small farmers under the crop + dairy farming system can increase their farm income via adoption of optimum farm plan.

In case of Kolar district, crop + dairy farmers were realizing an annual income of ₹ 168216 per farm per annum with the available capital of ₹ 132611 . In an optimum plan by spending ₹ 71391 per farm per annum, farmers could earn ₹ 115448 per farm per annum, which is almost ₹ 61220 less than the present available capital. An optimum plan suggested farmers to allocate more area towards ragi ( $0.92 \mathrm{ha}$ ) followed by mango ( 0.22 ha) with one dairy animal. It clearly shows that by efficient utilization of resources farmers could earn better income as farmers were over utilizing the available resources and getting meager profit.

Income, input utilization and cropping pattern in existing and normative plans for crop + dairy + sericulture farming system in the study area is presented in Table 3. In the existing cropping plan, farmers were realizing an annual income of ₹ 296433 per farm per annum with the total available expenditure of $₹ 274947$. In an optimum plan by spending ₹ 107598 per farm per annum farmers could earn ₹ 273169 per farm per annum by spending nearly 60 per cent less than the present spending availability. An optimum plan suggested farmers to allocate more area towards coconut (1.5 ha), followed by sericulture (0.4 ha), ragi ( 0.19 ha) with one dairy animal. In case of Kolar district, crop + dairy + sericulture farmers were realizing an annual income of ₹ 371893 per farm per annum with the total working capital of ₹ 147911. In an optimum plan by spending ₹ 137858 per farm per annum farmers could earn ₹ 263466 per farm per annum by spending almost $₹ 10053$ rupees less than the present available capital and without utilizing any credit. An optimum plan suggested farmers to allocate more area towards maize (0.78 ha) followed by sericulture (0.57 ha), ragi ( 0.22 ha) with 2 dairy animals. It clearly shows that crop + dairy + sericulture farmers of both the districts were over utilizing the resources to get small return, hence following of optimum farm plan helps the farmers to earn better income by effective utilization of resources.

Table 3: Income, input utilization and cropping pattern in existing and optimum plans for crop + dairy + sericulture farming system

\begin{tabular}{|c|c|c|c|c|c|}
\hline \multirow{2}{*}{$\begin{array}{l}\text { S1. } \\
\text { No. }\end{array}$} & \multirow{2}{*}{ Particular } & \multicolumn{2}{|c|}{ Existing plan } & \multicolumn{2}{|c|}{ Optimum plan } \\
\hline & & Mandya & Kolar & Mandya & Kolar \\
\hline \multirow[t]{2}{*}{1} & Area (acre) $\mathrm{Ra}$ & 1.70 & 1.00 & 1.70 & 1.00 \\
\hline & \multicolumn{2}{|c|}{ Irrigated 0.40} & 0.57 & 0.40 & 0.57 \\
\hline 2 & Income (₹) & 296433 & 371893 & 273169 & 263466 \\
\hline \multicolumn{6}{|c|}{ Input utilization } \\
\hline 3 & $\begin{array}{l}\text { Working or } \\
\text { available capital (₹) }\end{array}$ & 274947 & 147911 & 107598 & 137858 \\
\hline 4 & $\begin{array}{l}\text { Family labour (man } \\
\text { days) }\end{array}$ & 612 & 684 & 582 & 612 \\
\hline 5 & Fodder (q) & 23 & 6.20 & 130 & 259 \\
\hline 6 & FYM (t) & 3.80 & 6.30 & 2.40 & 3.54 \\
\hline 7 & Borrowed capital (₹) & ) 144750 & 110000 & 0 & 0 \\
\hline 8 & $\begin{array}{l}\text { Ragi consumption } \\
\text { per household }(\mathrm{kg})\end{array}$ & 268 & 286 & 268 & 286 \\
\hline 9 & $\begin{array}{l}\text { Milk consumption } \\
\text { per household (lt.) }\end{array}$ & 410 & 480 & 3882 & 7760 \\
\hline \multicolumn{6}{|c|}{ Cropping pattern } \\
\hline 10 & Paddy & 0.56 & - & 0.00 & - \\
\hline 11 & Ragi & 0.36 & 0.57 & 0.19 & 0.22 \\
\hline 12 & Sugarcane & 1.52 & - & 0.00 & - \\
\hline 13 & Cowpea & 0.12 & - & 0.00 & - \\
\hline 14 & Maize & & 0.48 & - & 0.78 \\
\hline 15 & Coconut & 0.08 & - & 1.50 & - \\
\hline 16 & Sericulture & 1.36 & 0.92 & 0.40 & 0.57 \\
\hline 17 & Dairy animal & 1.00 & 2.00 & 1.00 & 2.00 \\
\hline
\end{tabular}

Income, input utilization and cropping pattern in existing and normative plans for crop + dairy + horticulture farming system in the study area was given in the Table 4 . In the existing cropping plan farmers were realizing an annual income of ₹ 208174 per farm per annum with the total expenditure of ₹ 267651. In an optimum plan by spending ₹ 184254 per farm per annum farmers could earn ₹ 385107 per farm per annum by spending ₹ 83397 less than the existing expenditure. An optimum plan suggested 
farmers to allocate more area towards banana (1.00 ha) followed by coconut ( $0.53 \mathrm{ha})$, ragi ( $0.16 \mathrm{ha}$ ) with one dairy animal.

Table 4: Income, input utilization and cropping pattern in existing and optimum plans for crop + dairy + horticulture farming

\begin{tabular}{|c|c|c|c|c|c|}
\hline \multirow{2}{*}{$\begin{array}{l}\text { Sl. } \\
\text { No. }\end{array}$} & \multirow{2}{*}{ Particular } & \multicolumn{2}{|c|}{ Existing plan } & \multicolumn{2}{|c|}{ Optimum plan } \\
\hline & & Mandya & Kolar & Mandya & Kolar \\
\hline 1 & Area (acre) Rainfed & 0.70 & 2.30 & 2.42 & 2.30 \\
\hline & Irrigated & 1.00 & 0.95 & 1.50 & 0.95 \\
\hline 2 & Income (₹) & 208174 & 241089 & 385107 & 184414 \\
\hline \multicolumn{6}{|c|}{ Input utilization } \\
\hline 3 & $\begin{array}{l}\text { Working or } \\
\text { available capital (₹) }\end{array}$ & 267651 & 317089 & 184254 & 80299 \\
\hline 4 & $\begin{array}{l}\text { Family labour (man } \\
\text { days) }\end{array}$ & 684 & 684 & 274 & 124 \\
\hline 5 & Fodder (q) & 22 & 16 & 134 & 124 \\
\hline 6 & FYM (t) & 3.70 & 3.40 & 3.50 & 2.60 \\
\hline 7 & Borrowed capital (₹) & 81209 & 76000 & 0 & 0.00 \\
\hline 8 & $\begin{array}{l}\text { Ragi consumption } \\
\text { per household (kg) }\end{array}$ & 271 & 282 & 271 & 840 \\
\hline 9 & $\begin{array}{l}\text { Milk consumption } \\
\text { per household (lt.) }\end{array}$ & 414 & 412 & 3854 & 3840 \\
\hline \multicolumn{6}{|c|}{ Cropping pattern } \\
\hline 10 & Paddy & 0.40 & - & 0.00 & - \\
\hline 11 & Ragi & 0.14 & 0.32 & 0.16 & 0.60 \\
\hline 12 & Redgram & 0.40 & 0.08 & 0.00 & 0.00 \\
\hline 13 & Rainfed paddy & - & 0.06 & - & 0.00 \\
\hline 13 & Cowpea & 0.06 & - & 0.00 & - \\
\hline 14 & Maize & 0.40 & - & 0.00 & - \\
\hline 15 & Tomato & 0.20 & 0.24 & 0.00 & 0.00 \\
\hline 16 & Green chilli & - & 0.16 & & 0.00 \\
\hline 17 & Beans & 0.18 & 0.08 & 0.00 & 0.00 \\
\hline 18 & Carrot & 0.12 & - & 0.00 & - \\
\hline 19 & Banana & 0.12 & - & 1.00 & - \\
\hline 20 & Mango & - & 0.24 & - & 0.00 \\
\hline 21 & Guava & - & 0.08 & - & 0.38 \\
\hline 22 & Marigold & - & 0.06 & - & 0.00 \\
\hline 23 & Rose & - & 0.12 & - & 0.00 \\
\hline 24 & Coconut & 0.40 & - & 0.53 & - \\
\hline 25 & Dairy animal & 1.00 & 2.00 & 1.00 & 1.00 \\
\hline
\end{tabular}

In case of Kolar district, crop + dairy + horticulture farmers were realizing an annual income of ₹ 241089 per farm per annum with the total expenditure of ₹ 317089. In an optimum plan by spending ₹ 80299 per farm per annum farmers could earn ₹ 184414 per farm per annum by spending ₹ 236790 rupees less than the present available expenditure. An optimum plan suggested farmers to allocate more area towards guava $(0.38 \mathrm{ha})$ followed by ragi ( $0.6 \mathrm{ha})$ with one dairy animal.

\section{SUMMARY AND CONCLUSION}

The farming system with crops, dairy and sericulture components turn out to be remunerative among all type of farming systems. Hence, considering the technical feasibility of enterprises, efforts need to be made to popularize and strengthen dairy and sericulture-based farming systems among farm households. In order to sustain and improve the income, the designated models should be demonstrated in the farmer's fields to convince the farmers to follow the same, thus, there is a need efficient extension programs and extension officers to create awareness among farm households. To achieve this government development programmes through mass/electronic media, training and campaigns are very much necessary.

\section{REFERENCES}

Akpan, N.P. and Iwok, I.A. 2016. Application of linear programming for optimal use of raw materials in Bekary, Int. J. Mathematics and Statistics Invention, 4(8): 51-57.

Bhat, S., Rego, A.M., Jnanesh, N.A. and Dsouza, R.A. 2015. Application of Operations Research Technique to Improve the Performance of the HID of a Hospital. J. of Mechanical Engineering and Automation, 5(3B): 81-83.

Datta, S. and Bandyopadhyay, R. 1994. Applications of Operational Research in Industry and Industrialization in the Developing Countries. A Rev. Omega, 22(2): 173-184.

Ezema, I.B. and Amakon, O. 2012. Optimizing profit with the linear programming model: A focus on Golden plastic industry limited, Enugu, Nigeria. Interdiscip J. Res. Business, 2: 36-41.

Falcon, W., Naylor, R., Steinfield, H., Galloway, J., Smil, V., Bradfod, E., Alder, J. and Mooney, H. 2005. Agriculture, losing the links between livestock and land. J. of Sci., 310(57): 1621-1629.

Homayora, Y., Saifa, B.S., Shaila, S. and Mohammad, A.I. 2020. Efficient use of agricultural land in Bangladesh: Strategies for optimization. The Bangladesh J. of Agri. Econ., 41(1): 35-45.

http://www.fao.org/sustainable-development-goals/ indicators/en.pdf (Last accessed on $19^{\text {th }}$ August 2019).

https://eands.dacnet.nic.in( last accessed on $8^{\text {th }}$ October 2021).

Igwe, K.C, Onyenweaku, C.E. and Nwaru, J.C. 2011. Application of Linear Programming to semi-commercial arable and fishery enterprises in Abia State, Nigeria.Int. J. of Econ. and Mgt. Sci., 1(1): 55-68. 
Jithendra. 2018. News on Agriculture: NABARD report. Down to earth Pub.

Majeke, F., Majeke, J., Mufandaedza, J. and Shoka, M. 2013. Modeling a small farm livelihood system using linear programming in Bindura, Zimbabwe. Res. J. Mgt.Sci., 2(5): 20-23.

Memmah, M.M., Lescourret, F., Yao, X. and Lavignel, C. 2015. Metaheuristicsfor Agricultural Land Use Optimization: A Review. Agr. Sustain. Dev., 35: 975-998.

Mark, A.S. 1998. Linear programming for optimization. Perceptive scientific instruments, pp. 1-18.

Narayanamurthy. 2017. Farm income in India: Myths and realities. Ind. J. of Agri. Econ., 72(1): 14-20.
Surjith, V. 2017. The Evolution of farm income statistics in India: A review. Rev. of Agrarian Stu., 7(2).

Tamta, P., Singh, H.N., Singh, J., Ruhela, A., Pal, V.K. and Pant, M. 2016. Optimum farm planning under different farming systems on small and marginal farms in Rampur district, Uttar Pradesh: A linear programming approach. Int. J. Res. in Manag. Econ. and Commerce, 6(4): 42-53.

Zainab, N. 2010. A study on economic analysis of integrated farming systems in central dry zone of Karnataka. Thesis M. Sc. (Agri.). Thesis (Unpub.), Univ. of Agric. Sci., Bangaluru, Karnataka, India. 
